\title{
Attitude of Millennial Generation Towards Social Media Devices In Nigerian Universities
}

\author{
Chinelo Joy Ugwu Ugwu, Josephine Uzoamaka Anekwe \\ University of Port Harcourt, Rivers State, Nigeria
}

\begin{abstract}
The unprecedented interest of the millennial generation towards the use of social media devices (SMDs) has increasingly become a source of concern to academics in the Nigerian. A deviation from the planned academic culture, distraction and divided attention among the millennia's, occasioned by their engrossment in SMDs, necessitated this study. The study was carried out in four Nigerian universities; two federal and two state, with four research questions and five hypotheses guiding the study. The population comprised of 3,960 three hundred level (third year) students from both the federal and state universities. A stratified random sampling based on gender and individual consent was employed. The instrument used for data collection, developed by the researchers was titled "Attitude of the Millennial Generation towards Social Media Usage". The questionnaire was trial tested and the reliability co-efficient for the four sections were; $A=0.80 ; B=0.92, C=0.82, D=0.84$. Data were analyzed using mean, standard deviation and rank for research questions and an independent samples t-test was used to test the null hypotheses. The results showed that the millennials have a positive attitude towards the usage of SMDs for social activities but a negative attitude for using these devices for academic purposes. There is no significant difference in their attitude based on gender and WhatsApp, Instagram and Facebook were the most frequently used devices in the Nigerian universities. Some recommendations were made that the millennials should be refocused to using SMDs for academic purposes and not just social activities.
\end{abstract}

\section{Introduction}

The unprecedented interest of the millennial generation towards the usage of social media devices (SMDs) has increased on a daily basis and has become a source of interest for academics in Nigerian universities. Many authors (Ahmed [1], Akpan [2], and Duffett and Wakeham [11] supported the idea that social media devices and various types of phones are not only in use as substitutes for computers but have now become individuals' expansions of themselves especially among the millennial generation students. Some of these millennials are rapidly evolving with SMDs like YouTube, Instagram, WhatsApp and Facebook. The millennial generation's expectation is that the universities in Nigeria should provide easy accessibility through SMDs to a variety of services, which are needed for their education, professional activities and individual inclinations [1].

The millennial generation also referred to as generation Y, Z; Net or Next generation is a group of people with the most frequently used SMDs in the world today [14]. Generation Z being those born in the early 1990 to early 2000 . It is worth mentioning that both Generation Y and Generation Z could be referred to as "millennials". The only difference between them is the use of technology. Generation $\mathrm{Y}$ grew-up on personal computers, cellphones and video games, while generation $\mathrm{Z}$ has grown up on tablets, smartphones and apps [8]. Although the meeting point between them is that the two having significant effects in bringing changes in ways of communications and identity in globalized world. They further opined that the millennial generation is the people who were born between 1980s to the early 2000s. Birch [8] confirmed that $61 \%$ of the millennials are the people who are in the age brackets of eighteen (18) to twenty-four (24) years old. They are very much interested and close to their smartphones to a high extent that they normally sleep very close to them, using these devices as extension of their bodies and themselves. The millennials also have the orientation and interest of being connected digitally via the internet and other mobile technologies.

The unprecedented interest of the millennial generation towards the use of social media devices (SMDs) has increasingly become a source of concern to academics in the Nigerian universities. The high extent of their inclination to SMDs has brought serious challenges of poor academic performance by students and gross maladjusted behaviours leading to rapid decline in the quality of education. One witnesses a deviation from planned academic culture, distraction, lack of focus and divided attention among the 
millennials occasioned by their engrossment in the activities of SMDs. Instead of studying, they spend much time chatting and making friends via SMDs. Observations have shown that these millennials do not conform to the same attitude but have both positive or negative attitudes towards the usage of SMDs. They also have different reasons for using them and these uncertainties have formed the bases for this study.

Generally, more than $36 \%$ of the millennial group watch online videos than the overall population, as noted by Digital Future in Focus [8]. This scenario was influenced in a great way by the rise of free video sharing platforms like Vimeo, Vine, Instagram and YouTube. Social media as defined in [5] is the use of electronics means for communication and interaction among individuals who have common interest. Social media is grouped into technologies which are mediated to afford individuals, companies, NGOs, government and educational systems the opportunity to view, create and share information, ideas, career and interest through various ways of interactions and communications with virtual communities and networks [4].

The millennials have different attitudes towards particular issues. Their reactions to issues are functions of various factors such as social, economic, political, academic and other related factors. The millennials' attitudes are also divergent to issues as a result of individual background, which affect their mental perception of a given fact. Consequently, what one millennial perceives as negative could be perceived as positive by another millennial. This is as a function of variable factors. Attitude is viewed in psychology as an expression of favour or disfavor towards an object, be it an event, person, place or thing. This attitude can be a positive or negative evaluation of people, objects, activities and ideas [20]. Attitude could be described as a learned state of mind to react to an object or class of objects in a consistently favourable or unfavourable manner [12].

Corroborating with the above definition, businessdictionary.com defines attitude as the determination to respond in a positive or negative way towards a given idea, object, persons or events. Attitude has profound influence on how a person's choice of actions and reactions to problems, motivations and benefits. The online Business Dictionary has identified four key elements of attitude to be:

i) Affective, which shows one's inner feelings, love, interest and emotions.

ii) Cognitive, which deals with one's beliefs which an individual holds in a conscious manner.

iii) Conative, which shows the ability of a person to be inclined to certain actions or behaviour. iv) Evaluative, which concerns one's mental assessment that could be positively or negatively directed towards certain responses.

Many studies have examined the millennial generation's attitude towards the usage of SMDs both for academic purpose and in other areas of endeavour. A study by Onwuagboke and Singh [20] examined faculty attitude and use of ICT in instructional delivery in tertiary institutions in a developing nation. It was discovered that faculty attitude was positively correlated with the use of ICT in curriculum. The findings also reveal that although academic staff have positive attitude about the usage of ICT in instructional delivery for the millennials, they however reported low-level usage of ICT for instructional purposes. Similarly, the attitude of the millennials towards the usage of SMDs could be positive or negative. At times, their attitude could vary according to gender and by age. It is also necessary to find out the different reasons for using the SMDs and the most frequently used SMDs by the millennials. These uncertainties in attitude, whether positive or negative and whether this difference is according to gender calls for this research study.

The digital era has brought great changes and innovations in the ways through which millennials communicate and exchange ideas based on diverse issues. The SMDs have many affordances, which might have made the millennials be seduced by any SMDs service. This makes their lives easy, especially through innovative and efficient applications. They also help to increase students' collaboration [4].

The above affordances of SMDs are some of the reasons why the millennials use each of the SMDs like Facebook, YouTube, WhatsApp, Twitter, Instagram and Flickr. A study carried by World Wide Worx and Student Brands [11] reported that communication is the overriding factor for students' use of technology, with 97\% of these millennials using Facebook. Over 50\% of the millennials were found to be addicted to Social Networking Sites (SNS), with a quarter of them stressing that their smartphones and social media were given priority to their studies and $20 \%$ were found to be emotionally influenced by the things they saw on social media. These scenarios further, call for the investigation on the types of SMDs that are frequently used and reasons for their usage.

This study therefore has set out to ascertain the millennial generation students' attitude towards the usage of SMDs, the usage by gender, frequency of usage, and the reasons for using the identified SMDs. The poses a question, how would the millennial generation's attitude be refocused to have positive attitude and relevant reasons towards the usage of 
SMDs? Providing answers to the aforementioned question is the thrust of this study.

\section{Theoretical Backing of Social Media}

The advent of technology is reshaping patterns of social media use. As technology expands, theories equally emerge in response to technological change. Technology as seen in the 21 st century has many facets that affect the lives of people all over the world. New learning environments are the offspring of social cognition and social learning theories discussed below.

\subsection{Social Cognitive Theory}

Bandura [6] opined in social cognitive theory, that technology has opened the door for individuals to interact and observe others and to learn from social interactions for behavioural modifications. Students in general are besieged by various social interactions that convey meanings and spontaneous emotional reactions either through modeling, instruction or persuasive influence. Based on this fact, Bandura [7] affirmed that observational learning enables students to expand their knowledge and skills rapidly as a function of perceived information transmitted by the rich models experienced. Besides, modeling has been seen to be a major factor in social learning theory. The millennial students are very much involved in digital learning process to construct knowledge through modeling and related activities.

The fact is clear in that by direct experience, students construct their own meaning by observing the effects their actions have in a given situation. A case in point is learning by modeling. In other words, observing behaviors or the consequences of individual actions can stimulate the learning capabilities of the learners. Huitt [13] was of the opinion that social cognition has its base in social psychology, which probes the thoughts, feelings and behaviour of individuals as they influence others in the course of social interaction in the digital learning process.

\subsection{Social Learning Theory}

Sherman and Kurshan [22] opted to express that social activities allow students to air their views which enable them to develop their understanding with peers as they work on projects and interact with one another. As such, they stimulate their mental horizon for more effective understanding. As their understandings increase, achievement increases in all round activities. Alansari [20] noted the increase in achievement in "all ability levels (high, medium, low); higher-level thinking processes can result; a deeper level of understanding is possible and critical thinking is promoted." Again, in his research, he noted more positive peer interaction and understanding as they demonstrate social skills and render more social support for each other. This will result in higher level of esteem.

The impact of technology in social interactions is extensive. In this regard, online communities of students and adults who collaborate on specific problems are created [22]. These online communities necessitate social interaction, which stimulate studentto-student or student-to-professional communication and information sharing. In the process of interaction, technological understanding is imbued into the students, which increases their intellectual capacities as they communicate with others in the classes and other locations. Kop and Hill [14] pointed that the stream of information, which flows on the internet, is a means of harnessing new possibilities for individuals to communicate on global networks and enjoy the vast potentials of information stream.

In a study carried out by Olele [19] titled, "webbased facilities for teaching and learning: implications for internationalizing teacher education," she outlined three theories. One is connectivism. This theory deals with digital age, which indicates that learning and knowledge are based on diversity of opinions and in the process of connecting information sources using blogs and wikis in the social media.

The other theory is constructivism, which is based on learning by doing. In this, it stressed the need for learners to discover new ideas, explore and try the ideas by themselves. The third one is Communities of Practice (CoP). The CoP is a situation where people of a community with a common interest, profession, outlined objectives, come together to share ideas, resources and solve problems. They equally pull knowledge together, discuss issues and work as a body. They, in absolute totality, are involved in the use of social media in solving their problems as web-based tools to promote collaboration and co-operation.

\section{Objectives of the Study}

The objective of this study is to ascertain the millennial generation's attitude towards the usage of social media devices (SMDs) and to determine their reasons for using them. Specifically, the study is guided by four research questions.

\subsection{Research Questions}

1. What is the attitude of the millennials towards the usage of social media devices (SMDs) in the federal and state universities in Nigeria? 
2. Has gender any influence on the attitude of the millennials towards the usage of social media devices in the federal and state universities in Nigeria?

3. How frequently do the millennials of federal and state universities in Nigeria use the SMDs?

4. What are the reasons for using SMDs by the millennials of federal and state universities in Nigeria?

\subsection{Hypotheses}

Five research hypotheses were tested at a 0.05 level of significance.

1. There is no significant difference in the attitude of millennial generation students towards the usage of SMDs in federal and state universities in Nigeria.

2. There is no significant difference in the attitude of male and female millennials towards the usage of SMDs in federal and state universities in Nigeria.

3. There is no significant difference in the frequency with which millennials use the SMDs in federal and state universities.

4. The mean ratings of the millennials on how frequently they use SMDs in federal and state universities in Nigeria will not differ significantly.

5. The mean ratings of the millennials on the reasons for using SMDs in federal and state universities in Nigeria will not differ significantly.

\section{Methodology}

The study adopted a descriptive survey that was carried out in two federal and state universities in South-South zone of Nigeria. The target population consisted of all the third-year students from the faculties of education in the selected universities totaling 3,960. The target population from federal universities, University of Port Harcourt (Uniport), Rivers State and University of Calabar (Unical), Akwa Ibom State was 2,120 and from the state universities, Ignatius Ajuru University of Education, Rivers State and Niger Delta University, Bayelsa State, the target population was 1,840 .

Stratified random sampling technique based on gender, individual consent and the students in three hundred level were used to select the subjects. The total sample size for the study was 482 millennials. The sample from federal $=248$ (male $=130$ and female 118). The sample size from the state universities was 234 (male $=121$ and female 113). In all, male $=251$ and female $=231$.

The instrument used for data collection was a 38 item questionnaire titled, "Attitude of Millennial Generation towards Social Media Usage (AMGTSMU)". The respondents were expected to indicate their type of university, gender and their level in the university in section one. Section two is made up of section A which sought information on the millennials attitude towards the use of SMDs, section $B$ elicited information on the in attitude based on gender, section $\mathrm{C}$ was based on how frequently the millennials use SMDs and section D sought information on the reasons for using SMDs.

The weightings for research question 1 are positive and negative. The mean of 2.50 or above is regarded as positive while those 2.49 and below are regarded as negative. The research questions 1,2 and 4 were answered using the modified Likert Scale of; Strongly Agree $(\mathrm{SA})=4$ point; Agree $(\mathrm{A})=3$ points; Disagree $(\mathrm{D})=2$ points and Strongly Disagree $(\mathrm{SD})=1$ point. The weightings for research question 3 are; Always $=5$ points, Most Times $=4$ points, Sometimes $=3$ points, Rarely $=2$ points and Never $=1$ point. For ease of analysis, only Agree (SA) or Disagree (D) and positive or negative were used for research questions 1, 2 and 4 . For research questions regarding frequencies, rating 0.00-0.99 = Never, 1.00-1.99 = Rarely, 2.00-2.99 = Sometimes, 3.00-3.99 = Most times and 4.00-5.00

Two experts from the Department of Educational Psychology, Guidance and Counseling and one from the Department of Curriculum Studies and Educational Technology established face and content validation of the instrument. These experts were expected to examine the instrument, research questions, and purpose of the study and the structure of the items. Their corrections were affected which guided the final draft of the instrument. Twenty copies of the questionnaire were trial tested on 20 students from two federal and two state universities that were not part of the study in South-East Zone of Nigeria. Their mean ratings of the items were collated using Cronbach Alpha Coefficient which gave values viz a viz; Section $\mathrm{A}=0.80 ; \mathrm{B}=0.92 ; \mathrm{C}=0.81$ and $\mathrm{D}=0.84$. The instrument was administered, and the data collected and analyzed using mean, standard deviation and frequencies to answer the research questions while the independent sample t-test was used to test the hypotheses at a 0.05 level of significance.

\section{Results}

The results of this study are presented in Tables 1 , 2, 3, 4 and 5 .

Research Question 1: What is the attitude of the millennial generation towards the usage of social media devices in federal and state universities in Nigeria?

Hypothesis 1: There is no significant difference in the attitude of millennial generation students towards the 
usage of SMDs in federal and state universities in Nigeria.

Table 1. Mean and standard deviation for the attitude of millennia's towards the use of SMDs

\begin{tabular}{|l|c|c|c|c|c|}
\hline University & N & Mean & SD & df & Decision \\
\hline Federal & 248 & 34.13 & 8.306 & \multirow{2}{*}{480} & \multirow{2}{*}{ Accept } \\
\cline { 1 - 4 } State & 234 & 32.87 & 8.54 & & \\
\hline
\end{tabular}

The data in Table 1 above shows that the millennials in federal universities $(\mathrm{N}=248)$ had a mean of 34.13 (SD $=8.306$ ) while the millennials in state universities had a mean of $32.87(\mathrm{SD}=8.54)$. From the mean values of millennials, it can be seen that the millennials from both universities had positive attitude towards the usage of SMDs but those in federal universities are more positively disposed to the usage of SMDs than their counterparts in state universities.

Further analysis using independent sample t-test yielded a t-value of 1.647 at 480 degrees of freedom with a p-value of 0.100 , which was greater than the chosen alpha of 0.05 . This indicates that the difference in the obtained mean values of millennial students in both federal and state universities was not statistically significant. The null hypothesis was therefore retained.

Research Question 2: Has gender any influence on the attitude of the millennials towards the usage of the SMDs?

Hypothesis 2: There is no significant difference in the attitude of male and female millennials towards the usage of SMDs in federal and state universities in Nigeria.

Table 2. Mean and standard deviation for male and female millennials attitude towards SMDs

\begin{tabular}{|l|c|c|c|c|c|}
\hline University & N & Mean & SD & df & Decision \\
\hline Male & 251 & 33.96 & 8.62 & \multirow{2}{*}{480} & $\begin{array}{c}\text { Retain } \\
\mathrm{HO}_{2}\end{array}$ \\
\hline Female & 231 & 33.04 & 8.23 & & \multicolumn{1}{|c|}{40} \\
\hline
\end{tabular}

As shown in Table 2, male students had a mean value of 33.96 ( $\mathrm{SD}=8.62$ ) while female millennial students had a mean of $33.04(\mathrm{SD}=8.23)$ in their attitude towards the usage of SMDs. This result obtained indicates that gender had no influence in the attitude of millennials towards their usage of SMDs.

Further analysis using independent sample t-test confirmed the fact that male and female millennials' attitude towards SMDs was not statistically significant. This is because the value obtained 1.203 at 480 degrees of freedom yielded a p-value of 0.203 , which was greater than the chosen alpha of 0.05. The null hypothesis was therefore retained.

Research Question 3: How frequently do the millennials of federal and state universities use the SMDs?

Hypothesis 3: There is no significant difference in the frequency with which millennials use the SMDs in federal and state universities.

Table 3. Difference in millennial usage frequency of specific SMDs based on university ownership

\begin{tabular}{|c|c|c|c|c|}
\hline & & $\begin{array}{l}\text { University } \\
\text { Type }\end{array}$ & Mean & Frequency \\
\hline 1 & Facebook & $\begin{array}{l}\text { Federal } \\
\text { State }\end{array}$ & $\begin{array}{l}3.83 \\
3.94 \\
\end{array}$ & Most times \\
\hline 2 & Twitter & $\begin{array}{l}\text { Federal } \\
\text { State }\end{array}$ & $\begin{array}{l}2.62 \\
2.65\end{array}$ & Sometimes \\
\hline 3 & LinkedIn & $\begin{array}{l}\text { Federal } \\
\text { State }\end{array}$ & $\begin{array}{l}1.89 \\
1.91\end{array}$ & Rarely \\
\hline 4 & Google+ & $\begin{array}{l}\text { Federal } \\
\text { State }\end{array}$ & $\begin{array}{l}1.53 \\
1.58\end{array}$ & Rarely \\
\hline 5 & YouTube & $\begin{array}{l}\text { Federal } \\
\text { State }\end{array}$ & $\begin{array}{l}2.93 \\
2.95\end{array}$ & Rarely \\
\hline 6 & Pinterest & $\begin{array}{l}\text { Federal } \\
\text { State }\end{array}$ & $\begin{array}{l}1.65 \\
1.66 \\
\end{array}$ & Sometimes \\
\hline 7 & Instagram & $\begin{array}{l}\text { Federal } \\
\text { State }\end{array}$ & $\begin{array}{l}3.84 \\
3.68\end{array}$ & Most times \\
\hline 8 & Snapchat & $\begin{array}{l}\text { Federal } \\
\text { State }\end{array}$ & $\begin{array}{l}2.71 \\
2.73 \\
\end{array}$ & Sometimes \\
\hline 9 & Flickr & $\begin{array}{l}\text { Federal } \\
\text { State }\end{array}$ & $\begin{array}{l}1.64 \\
1.50\end{array}$ & Rarely \\
\hline 10 & Vine & $\begin{array}{l}\text { Federal } \\
\text { State }\end{array}$ & $\begin{array}{l}1.10 \\
1.11\end{array}$ & Rarely \\
\hline 11 & Meetup & $\begin{array}{l}\text { Federal } \\
\text { State }\end{array}$ & $\begin{array}{l}1.26 \\
1.26\end{array}$ & Rarely \\
\hline 12 & WhatsApp & $\begin{array}{l}\text { Federal } \\
\text { State }\end{array}$ & $\begin{array}{l}4.35 \\
4.30 \\
\end{array}$ & Always \\
\hline
\end{tabular}

The data analysis displayed in Table 3 indicates that for Facebook, the millennials in both federal and state universities use it most times, $\overline{\mathrm{X}}=3.83$ and 3.96 respectively. No significant difference between the frequency of millennial students in federal and state universities while Facebook, $\mathrm{t}(480)=0.280, \mathrm{p}=0.78$ $>0.05$. For the usage of Twitter, the millennial students in federal universities indicated that they use it sometimes $(\bar{X}=2.69, \mathrm{SD}=1.21)$, with their peers in state universities indicating that they also used it sometimes $(\overline{\mathrm{X}}=2.65, \mathrm{SD}=1.23)$. Further confirmation using the independent sample t-test 
revealed that there was no significant difference in the reported frequency of twitter usage $t(480)=0.317, p=$ $0.75>0.05$. When the frequency rating of LinkedIn by millennial students was analyzed, those in federal universities reported that they used it rarely $(\overline{\mathrm{X}}=1.89$, $\mathrm{SD}=0.99)$ and those in state universities indicated they also used it rarely $(\overline{\mathrm{X}}=1.91, \mathrm{SD}=1.00)$. The difference in frequency ratings of LinkedIn usage was found to be statistically insignificant, $\mathrm{t}(480)=0.35, \mathrm{p}$ $=0.73>0.05$.

For the frequency of Google plus usage, the millennials in federal universities reported that they use it rarely $(\overline{\mathrm{X}}=1.53, \mathrm{SD}=0.84)$, and those in state universities also reported that they used it rarely $(\overline{\mathrm{X}}=$ $1.58, \mathrm{SD}=0.87)$. Further, no significant difference in the response of the millennials in federal and state universities was reported, $\mathrm{t}=0.67, \mathrm{p}=0.51>0.05$.

For YouTube, a mean value of 2.93 was reported by the millennials in federal universities indicating that they use it sometimes, while those in state universities reported that they use it sometimes too. This is because their mean value was $2.95(\mathrm{SD}=1.08)$. No significant difference was however observed in the millennials rating from federal and state universities $(474)=0.18$, $\mathrm{p}=0.85>0.05$.

For frequency Pinterest by the millennials, those in federal universities reported that they used it rarely $(\overline{\mathrm{X}}$ $=1.65, \mathrm{SD}=0.85)$, with those attending state universities reported that they use it rarely $(\overline{\mathrm{X}}=1.66$, $\mathrm{SD}=0.93$ ). No significant difference was reported in the frequency of Pinterest usage between federal and state millennial students, $\mathrm{t}(480)=0.12, \mathrm{p}=0.91>$ 0.05 .

For Instagram, the millennials in the federal universities reported that they use it most times $(\overline{\mathrm{X}}=$ 4.11, $\mathrm{SD}=1.20$ ) while their counterparts in state universities reported that they use it sometimes $(\overline{\mathrm{X}}=$ 3.94, $\mathrm{SD}=1.26$ ). No significant difference was obtained in the frequency of Instagram usage by the millennial students in federal and state universities, $\mathrm{t}$ $(480)=1.46, \mathrm{p}=0.15>0.05$.

For Flicks, the millennials in federal universities reported that they use it rarely ( $\overline{\mathrm{X}}=1.64, \mathrm{SD}=0.79$ ), and those in state universities reported that they also use it rarely $(\bar{X}=1.50, \mathrm{SD}=0.70)$. However, the difference was found to be significant $\mathrm{t}(480)=2.06, \mathrm{p}$ $=0.04<0.05$.

For the SMD Vine, the millennial students in federal universities reported that they use it rarely $(\bar{X}$ $=1.10, \mathrm{SD}=0.43$ ) with those in state universities reporting that they also use it rarely $(\overline{\mathrm{X}}=1.11, \mathrm{SD}=$ 0.44 ). No significant difference was however obtained in the ratings of millennials in federal and state universities because the t-value obtained at 480 degree of freedom yielded a p-value of 0.79 which was greater than the chosen alpha of 0.05 .

For the usage of MeetUp, the statistical analysis revealed that the millennials in the federal universities use it rarely $(\overline{\mathrm{X}}=1.26, \mathrm{SD}=0.55)$ and those in state universities use it rarely too ( $\bar{X}=1.26, \mathrm{SD}=0.60)$.

Finally, for the usage of WhatsApp, the result from statistical analysis revealed that students in federal universities use the SMD "Always" ( $\overline{\mathrm{X}}=4.35, \mathrm{SD}=$ $0.04)$ and those in state universities also use it "Always" ( $\overline{\mathrm{X}}=4.30, \mathrm{SD}=0.04)$.

Research Question 4: What are the reasons for using the SMDs by the millennials of federal and state universities in Nigeria?

Hypothesis 4: The mean ratings of the millennials on how frequently they use SMDs in federal and state universities in Nigeria will not differ significantly.

Table 4. Mean and rank on the reasons for using SMDs by the millennials of federal and state universities

\begin{tabular}{|c|l|c|c|c|c|}
\hline & Items & \multicolumn{2}{|c|}{ Federal } & \multicolumn{2}{c|}{ State } \\
\hline & $\begin{array}{l}\text { Indicate your } \\
\text { reasons for } \\
\text { using SMDs }\end{array}$ & $\overline{\mathrm{X}}$ & Rank & $\overline{\mathrm{X}}$ & Rank \\
\hline 1 & $\begin{array}{l}\text { I use it for } \\
\text { viewing } \\
\text { videos instead } \\
\text { of television }\end{array}$ & 2.88 & $3^{\text {rd }}$ & 2.58 & $2^{\text {nd }}$ \\
\hline 2 & $\begin{array}{l}\text { I use it for } \\
\text { creating and } \\
\text { sharing } \\
\text { academic } \\
\text { ideas with my } \\
\text { school mates }\end{array}$ & 2.50 & $6^{\text {th }}$ & 2.51 & $5^{\text {th }}$ \\
\hline 3 & $\begin{array}{l}\text { I use it for } \\
\text { completing } \\
\text { class } \\
\text { assignments }\end{array}$ & 2.52 & $5^{\text {th }}$ & 2.50 & $6^{\text {th }}$ \\
\hline 4 & $\begin{array}{l}\text { I use it to } \\
\text { establish } \\
\text { relationships } \\
\text { with students } \\
\text { in other } \\
\text { universities }\end{array}$ & 2.58 & $4^{\text {th }}$ & 2.52 & $4^{\text {th }}$ \\
\hline 5 & $\begin{array}{l}\text { I use it for } \\
\text { communicating } \\
\text { with my } \\
\text { family } \\
\text { members }\end{array}$ & 2.95 & $2^{\text {nd }}$ & 2.55 & $3^{\text {rd }}$ \\
\hline
\end{tabular}




\begin{tabular}{|c|l|c|c|c|c|}
\hline 6 & $\begin{array}{l}\text { I use it for } \\
\text { viewing } \\
\text { pornographic } \\
\text { films }\end{array}$ & 2.25 & $7^{\text {th }}$ & 2.24 & $7^{\text {th }}$ \\
\hline 7 & $\begin{array}{l}\text { I use it mostly } \\
\text { for chatting } \\
\text { with people }\end{array}$ & 3.45 & $1^{\text {st }}$ & 3.35 & $1^{\text {st }}$ \\
\hline & Grand Mean & 2.72 & & 2.60 & \\
\hline
\end{tabular}

The data in Table 4 showed that all the listed items from $1-5$ scored up to 2.50 , which is the acceptable mean and item 7 also scored above the acceptable means of 2.50. These are indications that the millennials in both the federal and state universities used their SMDs mostly for chatting with people which ranked 1st, communication with family members ranked 2nd, for viewing videos instead of television ranked 3rd while establishing relationships with other students in other universities, solving class assignments, creating and sharing academic ideas with my school mates and using my SMDs for viewing pornographic films ranked 4th, 5th, 6th and 7th respectively. In the state universities, the millennial reported that they used their SMDs mostly for chatting with people which ranked 1st. Others in order of ranking are; using the SMDs for viewing videos instead of television (2nd), for communication with family members (3rd), establishing relationships with other students in other universities (4th) while using SMDs for creating and sharing academic ideas (5th), solving class assignments (6th) and viewing pornographic films (7th). The overall grand mean showed that the millennials in federal and state universities have good reasons for using SMDs. However, the millennials in federal universities slightly scored higher than their counterparts in state university indicating that the millennials in federal had better reasons for using SMDs than their peers in the state universities.

Hypothesis 5: The mean ratings of the millennials on the reasons for using SMDs in federal and state universities in Nigeria will not differ significantly.

Table 5. Difference on the reasons for using SMDs in federal and state universities

\begin{tabular}{|l|c|c|c|c|c|}
\hline & N & Mean & SD & df & Decision \\
\hline Federal & 248 & 2.72 & 0.74 & \multirow{2}{*}{480} & $\begin{array}{c}\text { Reject } \\
\mathrm{HO}_{5}\end{array}$ \\
\hline State & 234 & 2.60 & 0.47 & & \\
\hline
\end{tabular}

As shown in the table above, students in federal universities had a mean rating of 2.72 and standard deviation of 0.74 , while their peers in state universities reported a mean of 2.60 and standard deviation of 0.47 .
Further analysis using independent sample t-test revealed that a $t$-calculated value of 2.14 which was greater than the t-crit value of 1.960 at 0.05 level of significance. This indicates that the reason for using SMDs was significantly greater among students in federal universities than state universities. The null hypothesis was therefore rejected.

\section{Discussion of the Findings}

The findings in Table 1 revealed that the millennials in both federal and state universities had positive attitudes towards the usage of SMDs. Nevertheless, the millennials from the federal universities were more positively inclined to the usage of SMDs than those in the state universities in Nigeria. This finding is in line with the result in Duffett and Wakeham [11] who discovered that the attitude of the millennials towards advertising could be described as the inclination to react in a positive or negative way to specific marketing communications. Further, the author confirmed that prior research has revealed that attitudes towards advertising are efficient measures of communications effectiveness [16]. In another study carried by Anyanwu, Ossai-Onah and Iroeze [5], they reported that the undergraduates had positive attitude towards the use of social media tools in three selected tertiary institutions in Imo State University in Nigeria. This finding is also in line with the present study.

The independent sample t-test yielded no significant difference in the mean value obtained in both federal and state universities. The null hypothesis was therefore retained. The present finding agrees with the result in Duffett and Wakeham [11] on the effect on attitude when the length of usage of SMDs by the millennials was tested. It was discovered that the millennials who had used social media for five years and above displayed more favourable cognitive attitudes in awareness and knowledge. The millennials who had utilized social media for less than five years exhibited significantly positive liking and preference attitudes to communications on the online SMDs platforms.

The findings in Table 2 showed that gender had no significant influence in their attitude towards the usage of social media devices. This is in line with the finding in the research work done by Onwuagboke and Singh [20] who compared the attitude of the faculty member by gender and type of institute. The finding revealed no significant difference in attitude by gender towards the usage of Information, Communication and Technology (ICT) and in like manner, significant differences in attitude do not exist by type of institutions among the three types of tertiary institutions. The independent sample t-test showed no 
statistically significant difference and therefore the null hypothesis was retained. The study further revealed that the faculty attitude was correlated positively towards the usage of ICT in curriculum. This finding contradicts that of McGregor and Bazi [17] who found out that females have less access to power and thus should be limited to access to social media usage.

The data in Table 3 revealed that the SMDs always used by the millennials students of federal and state universities are WhatsApp, Instagram and Facebook with WhatsApp being the most frequently used. Twitter, YouTube and Snapchat were sometimes used while the Instagram was used most times. The SMDs that were rarely used as reported by the millennials included LinkedIn, Pinterest, Google+, Flickr, Vine and MeetUp while Instagram was sometimes used. The finding of the present study is in conformity with the result of the research work in Anyanwu, Ossai-Onah and Iroeze [5] who found out that Facebook ranked highest $(89.2 \%)$ in the list of SMDs that are used by the undergraduates. Contrary to this study, twitter was found to be next to Facebook while WhatsApp and Facebook were most frequently used, in the present study.

This study disagrees with the finding in Duffett and Wakeham [11] who reported that the most commonly used social medium globally is Facebook. Nevertheless, it is a known fact that social media devices have emerged which provides the millennials the opportunities to interact and communicate among friends and millennial students in the South-South part of Nigeria are not left out.

In Table 4, the finding revealed that the millennials in both federal and state universities had good reasons for using SMD, although their SMDs were mostly used for chatting with people. This fact was clearly shown from their overall mean of 2.72 and SD 0.74 for the federal universities and 2.60 and SD 0.47 for the state universities. The null hypothesis was significantly greater in federal universities than state ones. Therefore, the null hypothesis was rejected. The millennials used their SMDs for other good reasons like; establishing relationships with other students from other universities, solving class assignment and for creating and sharing academic ideas with their school mates. This finding corroborates the finding in Anyanwu, Ossai-Onah and Iroeze [5] who also found out that majority of the university students utilize SMDs for sharing of information with fellow students $=65.4 \%$, communication with friends $=70.4 \%$ and establishing relationship with friends from other institution, $59.6 \%$.

The revelation in the above finding was not satisfactory to discover that the millennials in both federal and state universities in Nigeria do not give priority attention to the use of SMDs for academic reasons rather they use them for chatting with friends. This finding also confirmed the findings in Anyanwu, Ossai-Onah and Iroeze [5] who in their findings lamented that a greater number of the undergraduates in Nigerian universities rarely used the social media for educational reasons. Further, they noted in their finding that the students of the universities perspectives of SMDs were focused on how to socialize.

Supporting the findings of the above study, the research result by Braguglia [9] found that three quarters of smartphones users never leave home without their phone and most of them used their voice and text messaging features most frequently for personal communication. More than $15 \%$ of the subjects to a survey which is similar to the present study would have rather preferred to drill their teeth instead of given up their phones for a week [10]. The use of SMDs for social activities is good but more time should be devoted to using them to improve their academic studies.

\section{Conclusion}

This study examined the millennial generation's attitude towards the usage of social media devices in federal and state universities in Nigeria. A group of people very intertwined with their smartphones and social media devices. One of their characteristics is that they tend to be more confident and optimistic in themselves whether they are right or wrong. The SMDs have varieties of affordances to the benefits of the millennials through innovative and efficient applications.

The millennials use SMDs for connections and interactions with other people nationally and internationally as well as solving academic problems and viewing videos. Literature and theories supporting the use of social media in education were reviewed. Four research questions and five hypotheses guided the study. The results showed that the millennials in both federal and state universities in Nigeria have positive attitude towards the use of SMDs. The study revealed that there is no significant difference in the attitude of male and female millennials in federal and state universities in Nigeria. It was revealed also that WhatsApp and Facebook were the most frequently used by the millennials, although WhatsApp had a higher mean score, but the respondents reported they used them always.

Conclusively, SMDs have been found to be very user friendly and very beneficial to them in that they allow users from across the globe to communicate in varied ways. Hence, they are very necessary in the academic world and beyond. To this end, the 
millennials are hereby encouraged to use their SMDs more for the enhancement of learning and overall improvement of their studies in university education.

\section{Recommendations}

Based on the findings of this study, the following recommendations are put forward:

1. Guidance counselors in both the federal and state universities should be organizing orientations for the millennials so as to refocus them on the potentials of SMDs in their learning and to be more positively focused in their usage of SMDs.

2. Digital immigrant teachers should always create times to admonish both male and female millennials on the adverse effects of using their SMDs mostly for chatting and WhatsApp especially during the class sessions.

3. Millennials who normally subscribe to WhatsApp and Facebook should be encouraged also to make sure that they make use of the platforms positively.

4. Parents, university lecturers, counselors and other stakeholders should encourage students to utilize their SMDs in ways that will promote their academic achievements. Their reasons for using SMDs should be majorly for creating educational groups and devising means of using them to improve their academic growth for themselves and that of their universities.

5. The guidance counselors, parents and the university lecturers should admonish both male and female millennials on the dangers inherent in using their SMDs for viewing pornographic films. This might lead to serious academic decline, although, this was insignificantly related.

6. Present day lecturers should be computer and internet friendly so they can post their academic work online for their students. This will give them the opportunity to utilize SMDs for academic purposes.

\section{Contributions to Knowledge}

1. This study has established the fact that social media could be very good tools for enhancement of educational activities if positively used by the millennial generation and the lecturers should encourage their usage for class activities.

2. The study has also established the need for digital immigrant teachers to avail themselves to technological training so as to meet up with the challenges of dealing with millennials' teaching approaches.

3. This study has revealed the expectations of the lecturers, guidance counselors and parents from the millennials. They should be alive to their responsibilities by visiting schools and organizing academic platforms to counsel the millennia's. Counsel should include the importance of academic achievements and the negative consequences associated with absolute consumption of social media. The millennial generation should be more focused on academic attainment than playing with social media devices every moment of the day.

\section{References}

[1] Ahmed, N. The Millennial Generation's Preferences and Usage of Mobile Devices In The U.S. Journal of Advertising, Public Relations and Marketing, 2012, pp. 2(1), 1-6.

[2] Akpan, C.P. ICT Competence and Lecturers' Job Efficiency in Universities In Cross Rivers State, Nigeria. International Journal of Humanities and Social Science, Promoting Ideas, USA, 2014, pp. 4(10), 259-266.

[3] Alansari, E. M. Implementation of Cooperative Learning In The Center Of Community Service And Continuing Education At Kuwait University. Australian Journal of Adult Learning, 2006, pp. 46(2), 265-282.

[4] Anekwe, J. U. \& Anyanwu J. Bridging the digital divide among the net generation students and digital immigrant teachers using social media. British Journal of Education, London, 2017, pp. 38-52.

[5] Anyanwu, E.U., Ossai-Onah, V.O. \& Iroeze, P. Use of Social Media Tools Among Nigerian Undergraduates In Three Selected Tertiary Institutions In Imo State, Nigeria. Journal of Information and Knowledge Management, 2013, pp. 4(2), 46-52.

[6] Bandura, A. Social Cognitive Theory. Annuals of child development. JIA Press, Greenwich, 1989, pp. 6, 1-60.

[7] Bandura, A. Social Cognitive Theory of Mass Communication, J. Bryant \& M. Oliver (Eds.), Media effects 3rd edition, Routledge, New York, 2009, pp. 94-124.

[8] Birch J., Are millennials too attached to their mobile devices? Retrieved June 14, 2014 from afterthemillennials.com/2014/06/24.

[9] Braguglia K.H, Cellular Telephone Use: A Survey of College Business Students, Journal of College Teaching \& Learning, 2008.

[10] Diamanduros, T., Downs, E., and Jenkins, S, J. (2008) The Role of School Psychologists in the Assessment, Prevention, and Intervention of Cyberbullying. Psychology in the Schools, 2008, pp. 693-704.

[11] Duffett, R.G. \& Wakeham, M. Social Media Marketing Communications Effect on Attitudes Among Millennials in South Africa. The African Journal of Information System, AJIS, 2016, pp. 8(3), 19-44. 
[12] Fishbein, M.A. Attitude and The Prediction Of Behavior. M. Fishbein (ed) Readings in attitude theory and measurement, Wiley, New York, 1967, pp. 477-492.

[13] Huitt, W. Social Cognition. Educational Psychology Interactive. Valdosta, G.A: Valdosta State University, 2006, Retrieved Mar. 13, 2009, from http://chiron.valdosta.edu// whuitt/col/soccog/soccog.html.

[14] Kop, R. \& Hill, A. Connectivism: Learning Theory of The Future or Vestige of The Past? International Review of Research in Open and Distance Learning, [online] 2008, pp. 9(3), 1-13.

[15] Lamar, B. \& Levon, A. Exploring Millennials' Social Media Use. Print Article ID: 20170510. Quirks.com, May 4th, 2017. Retrieved from http://www.quirks.com>article> Exploring millennials.

[16] Mackenzie, S.B., Lutz, R.J. \& Belch, G.E. The Role of Attitude Toward the Ad As A Mediator Of Advertising Effectiveness: A Test Of Competing Explanations. Journal of Marketing Research, American Marketing Association, USA, 1986, pp. 23(2), 130-143.

[17] McGregor, E \& Bazi, F, Gender Mainstreaming in Science and Technology, Commonwealth Secretariat, London, 2001.

[18] Obar, J. \& Wildman, S. Social Media Definition and The Governance Challenge: An Introduction to The Special Issue. Telecommunications Policy, Quello Center Working Paper No. 2647377, 2015, pp. 39(9), 1-6.

[19] Olele, C.N. Educational Technology for Nation Building: Way Forward for Teacher Education In Nigeria. Journal of Business and Educational Leadership, 2011, pp. $3(1), 38-46$.

[20] Onwuagboke, B.B.C. \& Singh, T.K.R. Faculty Attitude and Use Of ICT In Instructional Delivery In Tertiary Institutions In A Developing Nation. International Journal of Research Studies in Educational Technology, 2016, pp. 5(1), 77-88.

[21] Prensky, M. Digital Natives, Digital Immigrants. On the Horizon, MCB University Press, 2001, pp. 9(5), 1-6.

[22] Sherman, T. M. \& Kurshan, B. L., Constructing Learning: Using Technology to Support Teaching For Understanding. Learning \& Leading with Technology, International Society for Technology in Education, USA, 2005, pp. 32(5), 10-39. 